\title{
Paradigm Shifts, Scientific Revolutions and the Moral Justification of Experimentation on Nonhuman Animals
}

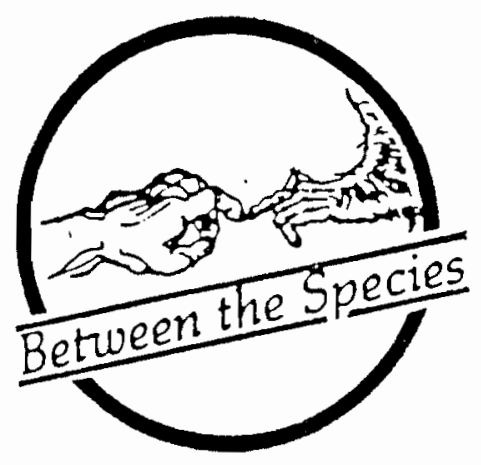

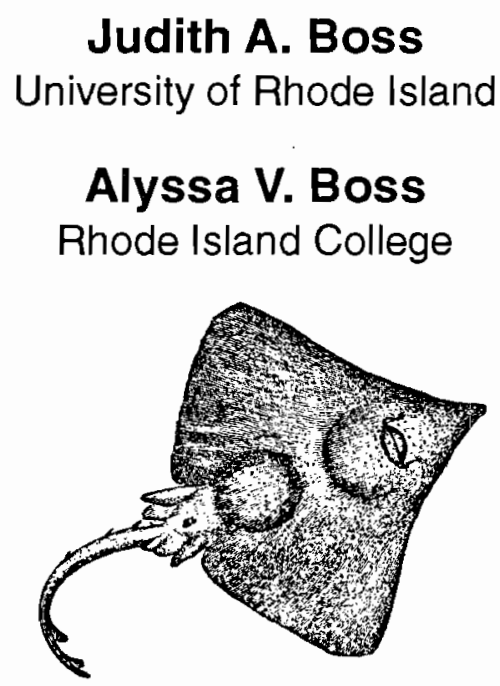

An estimated 70 to 120 million nonhuman animals are killed every year in scientific experiments. ${ }^{1}$ The justifications for the use of nonhuman animals in scientific experiments to benefit humans are based on two conflicting paradigms or models regarding the nature of human and nonhuman animals. This paper will trace the origins of these competing paradigms and the assumptions underlying each of them as they relate to scientific research.

According to Thomas Kuln, in his landmark work The Structure of Scientific Revolutions, when there are two competing and incompatible paradigms, one of them has eventually to give way to the other. ${ }^{2}$ Scientific revolutions, by their very nature, involve a shift from an old or traditional paradigm to a new paradigm. A paradigm shift, we will argue, is presently taking place in the biological sciences. The effect of this shift is currently being experienced in the conflict and uncertainty over what policies to adopt regarding the use of nonhuman animals in scientific experiments.

\section{The Traditional Paradigm \\ Underlying “Animal” Experimentation}

The traditional paradigm is based on a pseudo-scientific, anthropocentric, religious worldview which fails to stand up under philosophical and scientific scrutiny. It is based on the premise that there is a distinct line separating humans and other animals. Because of this, it is perfectly acceptable and even, according to some, morally required to use other animals in experiments to benefit humans or increase our knowledge.

The traditional paradigm forms the basis of the current approach to biological science, or what Kuhn calls "normal science." The term "normal science" refers to "research firmly based upon one or more past scientific achievements, achievements that some particular scientific community acknowledges for a time as supplying the foundation for its further practice."3 The purpose of education and textbooks is not to question or even explicate the basic paradigm, but to explain the accepted theories of normal science and to illustrate the successful application of these theories. In this way, the traditional paradigm is passed on to future generations of scientists. Only those who are willing to work within the accepted paradigm are welcome to participate in the community of scientists. Those who question the paradigm of "normal science"

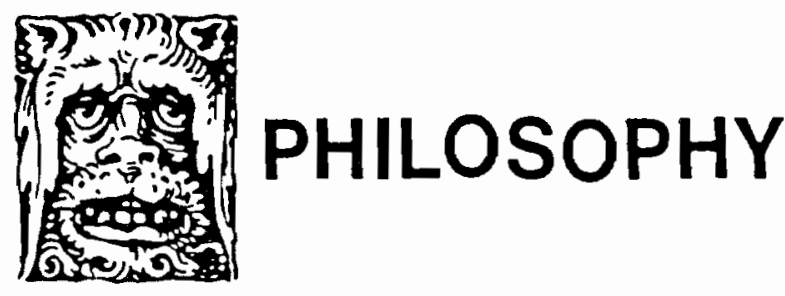


or refuse to accept it must either work in isolation or join a fringe group.

The traditional paradigm regarding "animal" experimentation was heavily influenced by the Greek philosophers, such as Aristotle, who argued that reason is an activity of the soul. Only the soul, which is nonmaterial and hence not restricted by the laws of nature, can act freely. Humans have a soul; nonhuman animals don't. This paradigm, which was Christianized by Thomas Aquinas, forms the basis of what is referred to as "traditional morality"-- the notion that only humans have intrinsic moral value. This philosophical tradition has been one of the most deeply rooted obstacles to serious consideration of the rights of nonhuman animals.

According to the Western Christian/philosophical worldview, the universe was created by God primarily as a home for humans, who were made in "His" image. The earth and all the creatures and other natural resources on the earth were put here by God to provide for human needs. Because of their special creation, humans alone among creatures partake of both the spiritual and material realms and, therefore, have a radically different nature that sets them apart from other animals.

"Humans," according to Thomas Aquinas, "are the highest in the order of material beings, yet the lowest in the order of spiritual beings... the progression from the non-living to luumans is one of increasing perfection... schematically, humans are at the apex of material creation." " Because we bear the closest likeness to God, humans are "highest" among creatures, and other animals and "things" are located on the scale depending on their resemblance to humans. Because animals are "durnb," to use Aquinas's term, and lack a soul, "it is not wrong for man to make use of them, either by killing or in any other way whatever."5

Environmentalist Lynn White maintains that Christianity is the most anthropocentric religion the world has ever seen. "By destroying pagan animism, Christianity made it possible to exploit nature in a mood of indifference to the feelings of natural objects." The Western belief that humans are separate from nature and have dominion over nature, he maintains, has enabled technological advance at the expense of nature and other animals.

This hierarchical model of the natural order has also been used to justify a hierarchy among different groups of humans, depending on their perceived level of rational activity. Thus, acceptance of the traditional paradigm has perpetuated not only the exploitation of nonluman animals as cxperimental subjects but discrimination, in scientific and medical research as well as society at large, against women and people of color.

Again, the male is by nature superior, and the female inferior... Where there is such a difference as that between soul and body, or between men and animals, the lower sort are by nature slaves, and it is better for them as for all inferiors that they should be under the rule of a master... indeed the use made of slaves and of tame animals is not very different. ${ }^{7}$

With only a few notable exceptions, modem Western philosophers have simply accepted anthropocentrism and the privileged status of humans, and men in particular, as a matter of fact. Rene Descartes, who is acknowledged to be the "Father of Modern Philosophy," wrote in his Discourse on Method (1637) that the rational soul could not be in any way derived from matter and that, therefore, the soul or mind is in its nature entirely independent of body. Humans are a combination of mind $/$ soul and body, while animals are entirely body and, hence, are merely machines. Even though he conceded that some nonhuman animals are capable of deceiving the shrewdest humans, Descartes did not take this to mean that they have thoughts. Instead, he regarded it is as proof that nonhuman animals act naturally and mechanically, like a clock which is able to give a more accurate reading of the time than is human judgment.

Descartes' philosophy heralded the beginning of the scientific revolution. However, despite his underlying epistemological principle that one must question everything, he did not question the paradigm underlying traditional morality but simply disguised the old religious language in more scientifically acceptable language. The immaterial soul is recast as disembodied intellect; science and technology now become the God; and humans are again given dominion over the earth by the new God-Science. By driving a wedge between human beings as disembodied intellects and other creatures as pure matter, Cartesian dualism permits humans to act as though other animals are simply "inanimate" resources to be used as we like.

Legitimating the traditional dualistic paradigm as the foundation of modern science was taken one step further by Descartes' contemporary Francis Bacon, one of the founders of the scientific method. While claiming that 
the scientific method has no religious or moral significance, Bacon at the same time unquestionably accepted the worldview that humans have the right and even the duty to manipulate nature and use other animals to satisfy human needs. Indeed, Bacon enthusiastically advocated vivisection for the pure joy of learning, without need of any moral justification, such as saving human lives. Because of the tremendous success of the scientific method in generating results and new technologies, and because of its claim to be value-neutral, few people bothered to question the moral and metaphysical assumptions underlying the scientific method.

Because it assumes a profound separation between intellect and body, the traditional paradigm has also resulted in free rein to express our intellect while simultaneously degrading and stifling emotions and instincts. Sigmund Freud, who incorporated the assumptions of this paradigm into psychoanalytic theory, maintained that in order for human civilization to succeed, instincts much be brought under control by the inind. ${ }^{8}$ Thus scientists, who are called to be disembodied intellects in the service of science, gradually became numb to the massive suffering of the nonhuman animals used in their experiments while at the same time being rewarded for seeking knowledge for knowledge's sake. "This rational, detached, scientific intellect, observing a world of which it is no longer a part," environmentalist and U.S. Vice President Al Gore notes, "is too often arrogant, unfeeling, uncaring. And its consequences can be monstrous."

Even the modern existentialists, who rejected much of traditional philosophy and ethics, and condemned the negative effects of modern science and technology on the human psyche, simply accepted without question traditional anthropocentric thinking. In a line of reasoning that sounds suspiciously reminiscent of Aquinas' and Descartes' mind/body dualism, Sartre argued that while other animals are born with an essence or nature, humans - being free and rational beingsare nothing but what they make of themselves. In other words, with humans "existence precedes essence," while with all other animals "essence precedes existence." Once again the disembodied rational intellect won out over emotions and instincts which were seen as nothing but functions of a mechanistic animal body.

This prejudice against nonhuman animals has been promoted by bolh Western theologians and philosophers who regard evil as something alien to the soul. Animals-as well as women and people of color who are regarded as less rational and more "instinctive" and emotional than white males-have been used as symbols of evil in the Western world ever since the serpent tempted Eve in the Garden of Eden. Animal welfare philosopher Mary Midgely notes that any evil on the part of humans is interpreted as "the debasing effect of matter seeping in through instinctive nature. This treacherous element clearly cannot be anything properly human; it must be described in animal terms. And no particular animal at that... In short, the Beast Within, whose only opponent is the rational soul."11

Nonhuman animals are typically portrayed as chaotic, uncontrolled and unpredictable, while humans are seen as rational and in control. Oddly, nonhuman animals, under the traditional paradigm, are at the same time held to have the exact opposite nature. They are machine-like and their behavior rigid, predetermined and governed by instincts. This prejudice is also maintained through language that degrades members of other species; he's an animal, a beast, a rat, a swine; she's catty, mousey, a bitch, a bird-brain. To act humanely, on the other hand, is to be kind and noble. To be a man is to show courage. Because of the assumption that everything other animals do is evil or inferior at best, it is concluded that it is morally justifiable to restrain them, to impose order on them, and to treat them as objects to be disposed of and experimented upon for the benefit of humans.

\section{Challenges to the Traditional Paradigm}

Challenges to the traditional paradigm have come from several fronts including Galileo's discovery that the earth is not the center of the universe, Darwinian evolutionary theory, Piaget's finding that logical thought can occur without language, concern for the rights of human subjects following the holocaust of World War II, the civil rights movement, and the environinental movement. The increasing evidence of irrational human brutality, and the alarming acceleration in the past few decades of environmental destruction because of human activities, including the extinction of thousands of species of plants and animals every year, has caused many people to rethink the traditional paradigm and to realize that humans are not separate from nature but a part of nature. It is becoming apparent, as we stand on the brink of ecological disaster, that it is the human animal, more than any other, that needs to be restrained and have order imposed on it. 
The assumption that the universe was created by God for human use was first called into question by Galileo's discovery in 1610 that the earth is not the center of the universe but just another celestial body, a theory which had already been proposed by Copernicus in 1543. As a result of his discovery, Galileo was charged by the authorities with subversion and heresy. Under pressure from the Church, he pleaded that he didn't really accept the implications of his discovery. With Galileo sufficiently subdued, the traditional paradigm based on the assumption that humans hold a special place in creation continued as the predominant worldview and the keystone of traditional morality.

The traditional paradigm suffered a further and more serious blow 250 years later with the publication of Charles Darwin's The Origin of Species in 1859. Although Darwin had already formulated his theory in 1838 , he was reluctant to publish the results. When the book was finally published, it was met with much public scorn as well as censure from the church. According to Darwin's theory of evolution, differences between humans and nonhuman animals were merely differences of degree rather than kind. In his later book, The Descent of Man, Darwin argued against the notion that humans differ greatly from "animals" because of humans" mental powers, pointing out that there is no fundamental difference between man and the higher animals in their mental faculties. Rather than being a unique and special creation, humans evolved from the same ancestors as the other animals. According to Kuhn,

For many men the abolition of the teleological kind of evolution was the most significant and least palatable of Darwin's suggestions. The Origin of Species recognized no goal set either by God or nature. Instead, natural selection was responsible for the gradual but steady emergence of more elaborate... specialized organisms which were products of a process that moved steadily from primitive beginnings but toward no goal... What could "evolution," "development" and "progress" mean in the absence of a specified goal? $?^{12}$

In other words, if humans are the result of natural forces without a plan or purpose, then how can one justify a moral theory based on the superiority of human nature? If we accept evolutionary biology, then there are no fixed essences but a multitude of organisms that resemble one another in some ways and not in others. Even within a species, some organisms are better adapted and more sentient than others. Consequently, moral treatment should depend on the individual qualities rather than an outdated notion like species' essence.

Darwin particularly attacked the assumption that only humans are capable of reason. Reasoning by definition involves the ability to form general rules from particular experiences. That other animals are clearly capable of reasoning seemed obvious to Darwin as well as to some of the other naturalists of his time. "Of all the faculties of the human mind," he wrote in his book The Descent of Man,

it will, I presume, be admitted that Reason stands at the summit. Only a few persons now dispute that animals possess some power of reasoning. Animals may constantly be seen to pause, deliberate, and resolve. It is a significant fact, that the more the habits of any particular animal are studied by a naturalist, the more he attributes to reason and the less to unlearnt instincts. ${ }^{13}$

Unfortunately, Darwin underestimated the power of the traditional paradigm in preventing humans from seeing rationality in other animals. The belief that nonhuman animals are unable to reason, and hence to make choices or act freely, was for a long time supported not only by religious doctrine but also by the belief that language is necessary for the formation of concepts which are, in turn, necessary for reason. Descartes, for example, argued that because animals lacked speech, i.e., were "dumb," a term which has come to mean both mute and stupid, this showed "not merely that the brutes have less reason than men, but that they have none at all, since it is clear that very little is required in order to be able to talk." 14 Therefore, according to Descartes, animals are forever trapped in the momentary.

Much of the success of normal science, according to Kuhn, lies in its ability to defend its basic assumptions, sometimes at considerable cost, and to suppress new findings that are seen as subversive and not consistent with it's basic worldview or paradigm. ${ }^{15}$ Normal science also defines which problems or phenomena should be studied. Kuhn writes: "Perhaps the most striking feature of the normal research problems we have just encountered is how little they 
aim to produce major novelties, conceptual or phenomenal." 16 In line with this, it is amazing how the assumption which equates mental concepts with language has gone unchallenged for so long.

Non-linguistic thinking is a field that has barely begun to be explored by science despite overwhelming evidence for its existence. The hidden cost of maintaining this assumption, which is basic to the traditional paradigm, is widespread discrimination against small children as well as nonhuman animals. While it is true that spoken language or a set of conventional signs is a fundamental tool for the adult human's mental life and formation of concepts, one cannot conclude from this that language is essential for a mental life. In fact, children under the age of one or two clearly have a mental life. Yet they lack language. Prior to this century, infants and young children, like other animals, were believed to be devoid of a mental or cognitive life and, hence, intrinsic moral value. ${ }^{17}$ However, child psychologist Jean Piaget found that instead of infants being passive and devoid of thought, the most rapid cognitive growth and learning in humans occurs prior to the age of two - and prior to language acquisition. ${ }^{18}$ Indeed, any argument that denies any sort of significant thought in the absence of language would find it difficult to explain how humans ever acquire language in the first place.

Many nonhuman animals are likewise clearly capable of reasoning and remembering. If they were not, it would be pointless to use them as subjects in learning experiments. Nonhuman animals obviously have concepts of food and danger, and they show evidence of having expectations of future events, such as rewards and punishments. A recent article in Scientific American states that "computers have mastered intellectual tasks such as chess and integral logic, but they have yet to attain the skills of a lobster in dealing with the real world."19

Behavioral evidence also supports the claim that other animals, like young humans, have memory without language. And memory depends on concept formation. Because we don't know how other animals do this without a system of conventional symbols does not mean that they don't do it. To use an analogy, if we adopted an ornithocentric or bird-centered worldview, we might claim that flying stands at the summit of all other achievements. Because all birds need feathers in order to fly, we might conclude that feathers are essential for flying. However, this is clearly false, since bats and butterflies and airplanes are also capable of flying. Of course, we are readily able to admit that non-birds are capable of flying, since our perception is not shaped by an ornithocentric worldview. However, if it were, we would probably devise all other sorts of other theories that are compatible with our paradigm to "explain" what these other beings are doing in the air without actually flying.

The claim that only humans are self-conscious or have a concept of self is also hard, if not impossible, to substantiate scientifically. The same criteria that we use in concluding that other humans are selfconscious-the formation and use of concepts, the realization that a particular experience is happening to them, the ability to learn from their experience, the efforts to protect themselves from harm-all point to the presence of self-consciousness in other animals. However, when scientists do try to apply the same criteria to humans and nonhuman animals, their observations are discounted amid accusations of anthropomorphism-one of the cardinal sins of normal science. In this way, traditional science avoids having to confront its anthropocentric assumptions by engaging in circular reasoning.

If nonhuman animals are incapable of making decisions or choices based on reason, they would be useless in learning experiments. "If we refuse to impute mental processes to other animals," notes philosopher and animal liberation advocate Peter Singer, "the logical consequence of this view of 'scientific methods' is that experiments on animals cannot teach us anything about human beings. As amazing as it may seem, some psychologists have been so concerned to avoid anthropomorphism that they have accepted this conclusion." 20

Thus, applying the traditional paradigm of "normal science" to scientific experimentation on nonhuman animals involves accepting contradictory premises: that other animals are fundamentally different from humans and that other animals are enough like humans that we can use them in research to make relatively accurate generalizations about human physiology and leaming. This flaw in the old paradigm is becoming increasingly apparent with the rapid growth of the animal liberation and animal welfare movements in the past few decades.

One of the means of maintaining a paradigm, according to Kuhn, is through language. For example, in the traditional paradigm the term "animal" is used, incorrectly, to refer to only "nonhuman animals"-- the 
term used by members of the animal liberation and animal welfare movements. The terms "sacrifice" or "termination" are used by adherents of "normal science" and the traditional paradigm when talking about "laboratory animals," rather than "euthanasia" or "killing"- terms reserved for the death of a human or a "pet." Different language is also used to describe the behavior of humans and nonhuman animals. However, the fact that the same response or behavior is described with behavioristic, mechanistic terms when speaking of nonhuman animals but with psychological mental terms or fuzzy philosophical terms such as "free will" when describing the same response or behavior in humans does not mean that the two are in fact different.

Another challenge to the traditional paradigm came through changes in our attitudes regarding the use of non-consenting humans in non-therapeutic experiments. Prior to World War II, there were very few regulations regarding the use of human subjects in scientific experiments. Following the war, with the growing public awareness of the atrocities committed in the name of science in the Nazi concentration camps, the traditional immunity of science from ethical scrutiny began to erode. Other studies conducted in this country, such as the Tuskegee syphilis study, the experiments on mentally retarded children at Willowbrook and the elderly at the Jewish Chronic Disease Hospital, and the use of prisoners as subjects in medical experimentsall studies which were regarded as morally acceptable by the scientific establishment at the time--were also publicly criticized.

As a result of this growing public awareness, strict regulations regarding human experimentation have been put in place to prevent the use in scientific experiments of humans lacking the cognitive or political power to assert their rights. The conviction that it is wrong to perform experiments on mentally defective, imprisoned or similarly marginalized humans has fueled the similar conviction that it is wrong and contrary to the principle of justice to do the same to other animals.

The impassioned battle for equal rights for all groups of humans during the various civil rights movements also fueled a demand for respect for the rights of other animals as well. The principle of equality among humans is not based on an empirical description of actual equality of humans but upon a moral ideal of equal concern for the well-being of others. An implication of this concern is that equal respect should apply to all beings regardless of their particular abilities, their intelligence or social standing. Indeed, many people who were engaged in the movements for equal rights for humans, such as Mahatma Gandhi, Mary Wollstonecraft, Lord Shaftesbury, Susan B. Anthony, Elizabeth Cady Stanton, and Horace Greeley, to name only a few, were also involved in the animals rights movement. ${ }^{21}$ These people in turn, and in particular Gandhi who was adamantly opposed to the exploitation of nonhuman animals, had a large impact on the American Civil Rights movement of the 1960's. Gandhi's basic philosophy centered on the interconnectedness of all life and the importance of extending moral respect to all living beings if we are to ever have a peaceful world.

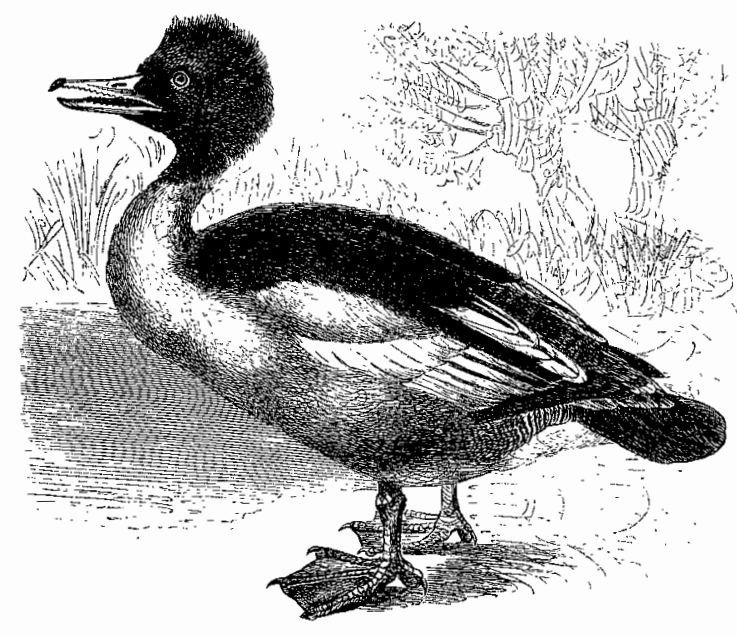

\section{Making the Shift}

Because of the heavy investment of traditional scientists in a particular paradigm, scientific revolutions rarely occur overnight or even in a single generation. This is especially true in areas of science which are insulated from the general public and whose publications are primarily in journals geared only toward others in the field or related fields. In the early stages of the development of a new paradigm, attention tends to be focused on the development of new alternatives. ${ }^{22}$

The emergence of a new paradigm from competing alternatives, according to Kuhn, is generally "preceded 
or accompanied by fundamental philosophical analysis of the contemporary research tradition." ${ }^{23}$ In light of this observation, it should come as no surprise that many of the leaders of the animal rights movement are social reformers, philosophers and ethicists who came from outside of normal science.

Paradigm shifts generally occur when a new paradigm eventually gains enough adherents to make their voice heard. Since 1980, the membership of animal protection groups, while still representing a minority of the population, has increased five to tenfold. ${ }^{24}$ Supporters of a new paradigm are generally members of the laity or restricted to a narrow subdivision, generally newcomers, of the scientific community who are not committed to the traditional rules of normal science.

The Animal Welfare Act, which was first enacted in 1970 and has since undergone many amendments, acts as a bridge between the traditional anthropocentric paradigm and the new emerging paradigm. While the Act neither accepts equal rights for nonhuman animals used as subjects in experiments, nor grants the same protection to "laboratory animals" as it does to cats, dogs and primates, it requires that researchers at least respect certain welfare rights and interests of their subjects.

Paradigm shifts are more likely to occur during a time of crisis, when normal science is unable to solve a particular problem. The threat of global ecological disaster, while still denied by many scientists, may be such a crisis. As such it requires that humans, as a species, reassess their relationship to the earth as well as to their technology. New paradigms require that people see the world, including other species of animals, in a radically new way. This means a complete re-evaluation of the traditional anthropocentric morality which allows us to exploit other animals and the environment. Because the use of "animal" research in the scientific and medical research community is so thoroughly entrenched, there is tremendous resistance to doing so.

When a paradigm shift occurs, there is inevitably conflict and heated debate as the two competing views openly clash. When a paradigm shift occurs, some of the old problems that were considered trivial or nonexistent, such as the morally significant difference between humans and other animals and the rights and welfare of nonhuman animals and the environment, become the "very archetypes of significant scientific advancement." 25
According to Kuhn, "normal science-- that put forth in traditional textbooks - often suppresses fundamental novelties because they are necessarily subversive of its basic commitments." ${ }^{26}$ One of the present commitments is to the use of nonhuman animals in scientific research. "Once a pattern of animal experimentation becomes the accepted mode of research in a particular field," Singer notes, "The process is self-reinforcing and difficult to break." ${ }^{27}$ A whole system of rewards, including tenure, the award of research grants, publication and scientific achievement, is invested in acceptance of the traditional paradigm. For this reason, arguments in support of animal research based on the benefits derived from it are essentially unresolvable. Even if valuable discoveries have been made using nonhuman animals, we cannot say how successful medical and scientific research would have been if it had been compelled, from the beginning, to develop alternative methods of investigation or if it had addressed itself to a different set of medical problems, such as preventive medicine or world health or environmentally-related issues.

Regarding the moral assumptions underlying scientific research, philosopher James Rachels maintains that we have reached that point in the paradigm shift where the old traditional morality needs to give way to a new ethics based on moral individualism in which species or group membership is relatively unimportant.

What has made it pressing is not simply a
faddish interest taken by philosophers in
animals' welfare or animal rights. Rather, it is
an issue pressed upon us by the disintegration
of the pre-Darwinian way of understanding
nature. The... final step of the historical
process will be reached if and when a new
equilibrium is found in which our morality can
once again comfortably coexist with our
understanding of the world and our place in it. ${ }^{28}$

Kuhn points out that when scientists and other people who are heavily invested in a particular paradigm are confronted with an anomaly, they will "devise numerous articulation and ad hoc modifications of their theory in order to eliminate any apparent conflict." 29 For example, religious organizations, who have traditionally been guardians of the anthropocentric morality that underlies the traditional paradigm, have become increasingly involved in the environmental 
movement. This, however, places churches in the uncomfortable position of being accused of being one of the primary causes of the current crisis by condoning exploitation of the earth's resources for human advancement, while at the same time trying to promote themselves as the beneficent caretakers of the earth.

In response to these accusations, Christian apologists, such as $\mathrm{Al}$ Gore, argue that the correct interpretation of Biblical Christianity is that humans, rather than dominating nature, are called upon to be "stewards" of the earth. ${ }^{30}$ However, this is simply a rewording of the traditional paradigm rather than a real shift. The concept of "stewardship" still implies that humans have privileged status vis-a-vis the rest of animals and nature. The paternalism implicit in the stewardship model reduces other animals to being permanently childlike and incapable of caring for themselves without our guidance and control. Also, the stewardship model is still focused on caring for the earth so that future generations of humans may benefit from its resources rather than on genuine respect for other living beings. Given the heavy investment most religious organizations have in the traditional anthropocentric paradigm, it is not surprising that they have been silent for the most part on the issue of the exploitation of nonhuman animals in scientific research to benefit humans.

Another more radical alternative paradigm has been put forth by feminist theologians, such as Sallie McFague, author of The Body of God: An Ecological Theology (1993). Using the Big Bang theory as support for the unity and common source of all being, the universe is envisioned in this paradigm as the incarnated body of God, rather than as being separate from and the creation of a transcendent, disembodied God. While the implications of this paradigm have yet to be worked out by its proponents, it would seem to require us to acknowledge the divinity and intrinsic moral worth of all beings, including laboratory animals, rather than just humans.

The strategy of making ad hoc modifications in theories in order to avoid conflict or having to give up the traditional paradigm also occurs among scientists. For example, R.G. Frey and W. Paton, defenders of the use of nonhuman animals in scientific experiments, admit that equality in terms of life and interests of some humans and some nonhuman animals is a problem that needs to be taken more seriously when designing experiments. According to the principle of justice,
"When individuals are treated differently, we need to point to a difference between them that justifies the differences in treatment." ${ }^{31}$ Mere difference in species is not enough to justify differences in treatment by scientists any more than is mere difference in group membership sufficient to justify paying a woman or an African-American less or denying them a job. To discriminate solely on the bases of gender or race constitutes sexism or racism. To discriminate solely on the basis of species constitutes what Singer terms "speciesism." Singer's rule of thumb for avoiding speciesism is that "we should give the same respect to the lives of animals as we give to the lives of those humans at a similar mental level," 32

Applying this rule to animal experimentation, Frey and Paton observe that:
We do not do to defective humans all that we presently do in our laboratories to quite healthy animals. My interest is in why we do not. If the justification is that we think human life of greater value than animals' life, then we must be prepared to face the facts, at least on the grounds I suggested, that (1) not all human life is of the same value and (ii) some human life has a value so low as to be exceeded by some animal life. ${ }^{33}$

However, rather that relinquish the traditional paradigm, Frey and Paton conclude that, in accordance with the principle of justice as explicated by Singer and Rachels, experimentation on healthy sentient mammals also justifies similar experimentation on human with similar or lower capacities.

One of the weaknesses of the alternative based on this version of the principle of justice is that it is still basically anthropocentric in that it respects nonhuman life only to the extent that it resembles sentient human life. Indeed, Singer limits his opposition to scientific experimentation using nonhuman animals primarily to those done on mammals.

Another alternative paradigm is that based on rights ethics rather than the principle of justice. Traditional morality supports a model of rights based on selfassertion. The model of rights adopted by most civil rights and animals rights activists, on the other hand, is based on interests. According to the self-assertion model, a right "is a claim, or potential claim, that one party may exercise against another. Rights arise, and can be intelligibly 
defended, only among beings who actually do, or can, make moral claims against one another." 34 This model, which is steeped in traditional dualistic ethics, assumes that only humans have rights, since "nonhuman animals lack this capacity for moral choice." 35

However, this description of human and nonhuman animals is inaccurate. Many nonhuman animals, as well as small children, respond with indignation, which is anger at an injustice, when their interests or needs are ignored or thwarted. They certainly seem to be recognizing and responding to moral claims. Another problem with this concept of rights is that we do recognize and protect, though not to the same extent that we protect the rights of adults, ${ }^{36}$ the rights of small children and humans with severe brain damage despite the fact that they are not generally recognized as being capable of free moral judgment, and in some cases have no potential for rationality.

Under the self-assertion model of rights, being able to claim one's rights boils down to having the power, generally political power, to successfully assert oneself. Basing rights on one's power to assert oneself, or the presence of an effective agent who will act on one's behalf, allows us to disregard not only the rights of nonhuman animals but also the rights of disempowered groups of humans who lack the political power or force of law to exercise their moral claims.

Philosophical concepts and the paradigms they support do not exist in a vacuum but have real-life consequences. This model of rights has contributed to the belief that humans in positions of power, such as scientists and medical doctors, have the right to assert their power over and exploit other species of animals in the name of science with little concern for their weifare, and in ways that would be considered as cruel and immoral if done by someone in a lesser position of power. Indeed, as was pointed out earlier, this model of rights was used at one time to justify the use in scientific experiments, without their informed consent, of groups of people who lacked political power.

The second model of rights, which is part of a newly emerging non-anthropocentric paradigm, is based on the principle of equal consideration of interests. The existence of interests is based on the capacity for suffering and for enjoyment. Humans are seen as members of a wider animal community, or a web of life, rather than as being a special and unique creation. All sentient animals, including humans, have an interest in doing that which brings pleasure as well as an interest in avoiding harm and suffering. Beings, however, have a right to pursue only their legitimate interests - that is, those interests that do not prevent others from pursuing their similar interests. Under this model of rights, benefits to oneself and others are morally acceptable only if no one else's rights have been violated in achieving these benefits. For example, we can't sacrifice the life of one child in a medical experiment to save the lives of fifty others.

Not all animals have the same interests. There are distinctly human rights, such as the right to religious freedom and the right to a formal education, that other animals lack since they have no interest in organized religion or formal schooling. On the other hand, all sentient animals, including humans, cats and mice, have an interest in not being tortured, not because they are capable of rational thought, but because they have the capacity to feel pain. In recognition of this, the Animal Welfare Act prohibits experiments that cause nonhumans animals unnecessary pain.

The need for one's space also does not ground a distinctive human right but one belonging to all territorial animals. Property or territorial rights belong to more than just humans since squirrels and mice and many other animals also need property or territory for collecting food and raising their young. This right is recognized and minimally respected in the Animal Welfare Act and its amendments regulating minimum space requirements for different "laboratory animals," so called. The Animal Welfare Act also expects experimenters to respect animals' interests in health care, proper nutrition and a clean living space. However, it does not recognize their liberty rights or right to life. Rachels notes in this regard that
While it is generally acknowledged by philosophers that liberty and freedom from coercion are essential if we humans are to develop and lead the types of lives where we can exercise our powers as rational agents, it is also true that liberty is necessary for many nonhuman animals if they are to live the sorts of lives, and thrive, in ways that are natural to them. ${ }^{37}$

In justifying the conscription of nonhuman animals for scientific experiments, the argument that humans can only be used if they give their informed consent, but other animals can be used because they are incapable 
of giving informed consent, is simply illogical and a good candidate for doublethink. Because other animals have an interest in liberty, field experiments are morally preferable to ones where animals are held captive in laboratories or where there is insufficient space for them to pursue their interests.

Despite the claims of those who adhere to the traditional paradigm, which assigns moral value based on the possession of autonomy and rationality, the moral relevance of sentience, rather than intelligence, is recognized in the prohibition against the use of severely mentally retarded humans in painful non-therapeutic medical research. However, if a higher degree of intelligence does not justify one human using another merely sentient human in scientific research, without their consent, then how can it entitle humans to exploit sentient nonhuman animals for the same purpose?

The clash between competing paradigms can result in deep chasms and misunderstandings between the factions because of the difference in basic assumptions and the different use of key terms. It is a terrible thing when someone, especially people who are not directly involved in the field under attack, accuse scientists of having dedicated their whole lives to pursuing a cruel and immoral vocation. We believe that all of us desire, at least at some level, to do what is right and good. People who claim that "animal" researchers are intentionally cruel are simply mistaken, except perhaps in a few idiosyncratic cases. In the great majority of cases, scientists using nonhuman animals in their research have motives which are noble and aimed at benefiting humans.

At the same time, we can all improve. Martin Luther King, Jr. once said that the "Universe bends toward justice." There are times in all our lives when, upon reflection, we realize that the end does not always justify the means and that we can do better in making this a more compassionate and just world.

\section{Seeking Viable Alternatives}

The claim that putting an end to all or most research using nonhuman animals would bring scientific progress to a halt is surely an exaggeration, as well as an indication of how some scientists are unable to see beyond the old paradigm. In fact, it was not too long ago that some scientists felt that the use of human subjects, without their consent, was necessary for scientific progress. Similarly, "those scientists who have convinced themselves that there can't be viable scientific alternatives to the use of animals in research," Tom Regan contends, "are captives of mental habits that science abhors. ${ }^{38}$ Rather than stopping all research, scientists are now being called by the newly emerging paradigm and the new ethics to redirect their practice from using nonhuman animals toward using more just alternative methods of scientific research.

The current paradigm shift is marked by a growing interest in the topic of alternatives to research using nonhuman animals. The concept of alternatives was developed by two British scientists, W.M. Russell and L.R. Burch, in 1959 and involves the principle of the "Three R's": Replacement, Reduction and Refinement.

The first " $R$," replacement, refers to situations where techniques, such as mathematical and computer models and tissue cultures, can be substituted for those using nonhuman animals. Also, in some cases, informed, consenting humans subjects could be used in place of nonhuman subjects. For example, there is no shortage of people with AIDS who would like to volunteer to be subjects in experiments designed to find a cure for AIDS. ${ }^{39}$ The fact that it might be less convenient to carry out research on humans instead of captive animals does not in itself justify using nonhuman animals. When alternative, morally acceptable techniques are available, they ought to be used.

Reduction refers to cutting back, whenever possible, on the number of nonhuman animals used in experiments. This involves the elimination of experiments that test trivial hypotheses or hypotheses whose truth or falsity is already sufficiently established, poorly designed experiments, and the use of nonhuman animals in experiments for duplication of drugs by competing firms. When nonhuman animals are used, the minimum number necessary for results should be used. For example, the National Cancer Institute in the course of only a few years has reduced the number of rodents used in cancer research by $80-90 \%$. The Institute is switching to the use of cell culture screening systems which are turning out to work better than the standard nonhuman animal model systems. ${ }^{40}$

The third " $R$," refinement, refers to the modification of techniques to reduce the pain and distress suffered by laboratory animals. In line with this, animal welfare legislation now requires that principle investigators minimize animal pain and distress in their research projects.

We would also like to add a fourth "R": Respect. The experimental design should be compatible with 
respect, not only for nonhuman animal subjects, but also, if you are a user, for yourself as a researcher. Do you feel you are compromising your own moral dignity or that of those who work with you by participating in this experiment? Using captive animals places the experimenter in a position of superiority. When we hold a position of power over others--humans or nonhuman animals- this often turns into contempt for those we have power over, as well as a numbing toward their suffering. In experimentation using nonhuman animals, this contempt might be exhibited not only in a debased attitude toward "laboratory animals" but toward nonhumạn animals in general.

A last question to ask is whether the experimental design can pass the test of publicity. The test of publicity states that we should do only those actions which a reasonable person or persons would deem morally acceptable. How do others, especially those new to the field or outside the field, respond to the experiment? Young children especially, have not yet been socialized in the traditional paradigm which teaches them to regard other animals as "things." Consequently, they often develop close relationships with members of other species such as a cat or dog. Would you feel good about using one of your childhood animal companions in your experiment? If not, why not?

Philosopher David Hume believed that although reason may inform our moral decisions, it is sentiment or feeling that actually moves us to act on these decisions. ${ }^{41}$ In deciding whether it is morally acceptable to use nonhuman animals in your particular experiment, you should listen to others-especially young people and others who are not so heavily invested in the old traditional paradigm; then listen to your own heart.

\section{Conclusion}

It is only by reference to religious myths and paradigms that we can justify a strict moral separation of humans and other animals. Science does not provide the criteria for such a division. As Mary Midgley points out: "Animals are not just one of the things with which people amuse themselves, like chewing-gum and water skis, they are the group to which people belong. We are not just rather like animals; we are animals."42

The traditional pre-Darwinian paradigm holds that our species, as well as other species, have an immutable nature fixed by God. This paradigm has been used to justify the belief, which is still prevalent among scientists, that humans as a group have a privileged, partly divine nature or essence, while other animals are qualitatively different. Darwinian evolutionary biology, on the other hand, implies something very different.

The anthropocentric religious worldview began breaking up long before Darwin, with the knowledge that the earth is not the center of the universe but just another celestial body. The job was, in theory at least, completed by Darwin with the finding that human beings are not the center or apex of creation but, rather, members of a widely diverse animal community. However, knowledge alone does not mean abandonment of an entrenched worldview. Sometimes this process takes centuries.

While the moral ideal under the new ethics and the emerging post-modern paradigm would be to cease all non-therapeutic or coercive research on captive nonhuman animals, the four " $\mathrm{R}$ ' $\mathrm{s}$ " at least point us in this direction. At the same time, some of the proposed alternatives, while using scientific rather than religious descriptions of human and nonhuman animals, are still somewhat anthropocentric in that they argue for the just and moral treatment of certain species of nonhuman animals, in particular mammals, because they have many characteristics in common with us.

As the "universe bends toward justice," if in fact this is happening, one can only hope that our concept of moral community will grow and become more inclusive. This new worldview is also going to force people to reexamine their attitudes toward other animals as sources of food, clothing, amusement and tethered companionship as well. Albert Schweitzer once said that we are not truly civilized if we concern ourselves only with the relation of humans to other humans. What is important is the relation of humans to all life..$^{43}$ Perhaps someday the new paradigm that will eventually replace the traditional paradigm will be similar to that espoused by Albert Schweitzer and Mahatma Gandhi and be based on respect for all living beings regardless of their resemblance to humans.

Until that time, the growing concern for the welfare and rights of nonbuman animals manifested in laws such as the Animal Welfare Act and in policy statements of such groups as the National Institute of Health (1985), the Council for International Organizations of Medical Science (1985), and other professional groups are surely steps in the right direction and, as such, are to be applauded. 


\section{Notes}

${ }^{1}$ Peter Singer, Animal Liberation (New York: Random House, 1990), p. 37.

${ }^{2}$ Thomas Kuhn, The Structure of Scientific Revolutions (Chicago: University of Chicago Press, 1970).

${ }^{3}$ Ibid., p. 10.

${ }^{4}$ Thomas Aquinas, Summa Contra Gentiles, Third Book, Part II, Chap. CXII. Extract from Tom Regan and Peter Singer, Animal Rights and Human Obligations, second edition (Englewood Cliffs, NJ: Prentice-Hall, 1989), pp. 58-59.

${ }^{5}$ Ibid., p. 59.

${ }^{6}$ Lynn White, "The Historic Roots of Our Ecological Crisis," Science 155 (1967), p. 1203.

${ }^{7}$ Aristotle, Politics, trans. by Ernest Baker (New York: Oxford University Press, 1948), pp. 11-14.

${ }^{8}$ Sigmund Freud, "Instincts and Their Vicissitudes," in The Standard Edition of the Complete Psychological Works of Sigmund Freud, ed. and trans. by James Strachey (London: The Hogarth Press and the Institute of Psycho-Analysis, 19531974), p. 118

${ }^{9}$ Albert Gore, Earth in the Balance: Ecology and the Human Spirit (Boston: Houghton Mifflin, 1992), p. 258.

${ }^{10} \mathrm{Jean}-\mathrm{Paul}$ Sartre, Existentialism and Human Emotions (New York: Philosophical Library, Inc.), pp. 15-18.

${ }^{11}$ Mary Midgley, "The Concept of Beastliness: Philosophy, Ethics and Animals' Behavior," Philosophy 48 (1973), p. 121.

${ }^{12}$ Kuhn, op. cit., p. 172.

${ }^{13}$ Charles Darwin, The Descent of Man, extract from Tom Regan and Peter Singer (eds.), Animal Rights and Human Obligations, op. cit., p. 30.

${ }^{14}$ Rene Descartes, Discourse on Method, extract from Tom Regan and Peter Singer (eds.), Animal Rights and Human Obligations, ibid., p. 15.

${ }^{15} \mathrm{Kuhn}$, op. cit., p. 5.

${ }^{16}$ Bid, p. 35.

${ }^{17}$ Catharine Damme, "Infanticide: The Worth of an Infant under Law," Medical History 22 (1978), pp. 1-24.

${ }^{18} \mathrm{Jean}$ Piaget, Judgment and Reasoning in Children (New York: Humanities Press, 1952).

${ }^{19}$ John Searle, Paul M. Churchland, and Patricia Smith Churchland, "Artificial Intelligence: A Debate," Scientific American 262 (1990), p. 25.
${ }^{20}$ Peter Singer, op, cit., p. 52.

${ }^{21}$ Ibid., pp. 221-222.

${ }^{22}$ Kuhn, op. cit., 76.

${ }^{23}$ Ibid., p. 70

${ }^{24}$ Andrew N. Rowan, "The Alternatives Concept," Animal Welfare Information Newsletter 2 (1991), p. 8.

${ }^{25}$ Kuhn, op. cit., p. 103.

${ }^{26} \mathrm{Ibid}$, p. 5.

${ }^{27}$ Singer, op. cit., pp. 90-91.

${ }^{28}$ James Rachels, "Darwin, Species, and Morality," extracted from Tom Regan and Peter Singer (eds.), Animal Rights and Human Obligations, op. cit., p. 103.

${ }^{29}$ Kuhn, op. cit., p. 78.

${ }^{30}$ Gore, op. cit., p. 243.

${ }^{31}$ James Rachels, "Why Animals Have a Right to Liberty," in Tom Regan and Peter Singer (eds.), Animals Rights and Human Obligations, op. cit., p. 98.

${ }^{32}$ Singer, op. cit., 21.

${ }^{33}$ Raymond G. Frey and William Paton, "Vivisection, Morals, and Medicine: An Exchange," Journal of Medical Ethics 9 (1983), p. 95.

${ }^{34}$ Carl Cohen, "The Case for the Use of Animals in Biomedical Research," New England Journal of Medicine 315 (1986), p. 865 .

${ }^{35}$ Ibid., p. 866.

${ }^{36}$ Damme, op. cit., p. 1.

${ }^{37}$ James Rachels, "Why Animals Have a Right to Liberty," op. cit., p. 120.

38 Tom Regan, The Case for Animal Rights (Berkeley, CA: The University of California Press, 1983), p. 455.

${ }^{39}$ Rowan, op. cit., pp. 1-2.

${ }^{40} \mathrm{lbid}$, p. p. 2.

${ }^{41}$ David Hume, Enquiry Concerning the Principles of Morals, Reprinted from the Edition of 1777 (LaSalle, IL: Open Court, 1946).

${ }^{42}$ Mary Midgley, op. cit., p. 114.

${ }^{43}$ Albert Schweitzer, The Philosophy of Civilization (New York: Macmillan Co., 1949). 